Iğdır Üniversitesi Fen Bilimleri Enstitüsü Dergisi, 11(2): 1603-1615, 2021

Journal of the Institute of Science and Technology, 11(2): 1603-1615, 2021

Field Crops
ISSN: 2146-0574, eISSN: 2536-4618 DOI: $10.21597 /$ jist.873537

Research Article

Received: 03-02-2021
Accepted: 28-02-2021

To Cite: Kumlay AM, Kaya C, Y1ldırım B, 2021. Different Plant Growth Regulators on Improvement of Potato (Solanum tuberosum L.) Micropropagation. Journal of the Institute of Science and Technology, 11(2): 1603-1615.

\title{
Different Plant Growth Regulators on Improvement of Potato (Solanum tuberosum L.) Micropropagation
}

\section{Ahmet Metin KUMLAY ${ }^{1 *}$, Canan KAYA², Bünyamin YILDIRIM ${ }^{1}$}

\begin{abstract}
The study compared the effects of MS medium containing $0.1 \mathrm{mg} \mathrm{L}^{-1}$ gibberellic acid $\left(\mathrm{GA}_{3}\right)$ and $\alpha$-naphthaleneacetic acid (NAA) in combination with $2.0 \mathrm{mg} \mathrm{L}^{-1}$ of kinetin (KIN), $2.0 \mathrm{mg} \mathrm{L}^{-}$ ${ }^{1}$ of benzyl aminopurine (BAP), $1.0 \mathrm{mg} \mathrm{L}^{-1}$ of zeatine riboside (ZR), and $0.5 \mathrm{mg} \mathrm{L}^{-1}$ of jasmonic acid (JA) for the micropropagation development of three potato (Solanum tuberosum L.) cultivars namely Caspar, Granola and Pasinler-92 using binodal stem explants. The results of this research clearly indicated that inclusion of JA among the other plant growth regulators significantly increased shoot regeneration and other characteristics of all potato cultivars used in the study. The minimum days to shoot proliferation on three cultivars ranged 4.0-5.5 d (best result on cv. Pasinler-92) on MS medium containing $0.5 \mathrm{mg} \mathrm{L}^{-1} \mathrm{JA}$. The minimum time to root initiation $(11.0 \mathrm{~d})$ was observed on cv. Pasinler92 on the same medium. The maximum number of axillary shoots (15.25) and nodes (19.0), maximum shoot length $(17.25 \mathrm{~cm})$, leaves (19.0) and roots (25.25) were noted on cv. Caspar. The longest roots $(18.45 \mathrm{~cm})$ on cv. Pasinler-92, and the maximum fresh weight $(404.87 \mathrm{mg})$ and dry weight $(61.85 \mathrm{mg})$ of plantlets from cv. Granola were also recorded on MS medium fortified with $0.1 \mathrm{mg} \mathrm{L}^{-1} \mathrm{GA}_{3}+0.1 \mathrm{mg}$ $\mathrm{L}^{-1} \mathrm{NAA}+0.5 \mathrm{mg} \mathrm{L}^{-1} \mathrm{JA}$.
\end{abstract}

Keywords: Potato, Solanum tuberosum L., micropropagation, in vitro, plant growth regulators

\footnotetext{
${ }^{1}$ Ahmet Metin KUMLAY (Orcid ID: 0000-0001-9765-8674) Bünyamin YILDIRIM (Orcid ID: 0000-0003-2463-6989), Department of Field Crops, Faculty of Agriculture, Igdir University, Igdir, Türkiye

${ }^{2}$ Canan KAYA (Orcid ID: 0000-0003-2014-5373), Eastern Anatolia Agricultural Research Institute, Erzurum, Türkiye

*Corresponding Author: Ahmet Metin KUMLAY, e-mail: akumlay@ hotmail.com

Bu çalışma 9-12 Mayıs 2018 tarihleri arasında Van Yüzüncüyıl Üniversitesi tarafından yapılan "I. International Agricultural Science Congress'de" özet bildiri olarak sunulmuştur.
} 


\section{INTRODUCTION}

Potato (Solanum tuberosum L.) is one of the significant industrial crops all over the world used for multipurposes. Researchers are always interested in improvement of tissue culture techniques of potato to increase high-quality pathogen-free plantlets production with consistent genetic and physiological traits that are highly efficient in terms of photosynthesis (Pruski, 2007; Mohapatra and Batra, 2017; de Morais et al., 2018). In vitro techniques could also be employed to stimulate the strength and improvement of potato breeding programs and to overcome negative effects related to conventional breeding methods (Tazeb, 2017). Previous reports suggest that the regeneration of potato is highly explant, PGR combinations and cultivar dependent (Hussain et al., 2005; Kumlay, 2014; Nuwagira et al., 2015; Naqvi et al., 2019). Under appropriate growth conditions, potato shoots, roots and stem explants with nodes have ability to regenerate, even without any plant growth regulators (PGRs) (Kumlay et al., 2014a; Quiroz et al., 2017; Kolachevskaya et al., 2019). However, regeneration of plantlets without PGRs is time extensive inducing low number of shoots, leaves and roots per explants (Kumlay, 2014). Therefore, adding exogenous PGRs is an effective way to accelerate plantlet regeneration and to reduce growth cycle during potato in vitro micropropagation (Kumlay et al., 2014b; Mendel et al., 2020). Most of the researchers prefer use of cytokinins with auxins to enhance root and shoot production (Ghaffoor et al., 2003; Kumlay and Eryiğit, 2011; Wani et al., 2018). Even though gibberellic acid $\left(\mathrm{GA}_{3}\right)$, cytokinins, auxins and jasmonic acid (JA) are thought to play a significant effect in arrangement of root and shoot development in potato in vitro (Kumlay and Eryiğit, 2011; Kumlay, 2016), there is no study reporting effects of these in combinations on improvement of potato micropropagation.

Previous studies suggest that higher concentrations of benzyl aminopurine (BAP) together with lower concentrations of $\alpha$-naphthaleneacetic acid (NAA), and $\mathrm{GA}_{3}$ induce shoot formation and organogenesis in potato (Hussain et al., 2005; Kaur et al., 2014). Mehmood et al. (2017) noted that potato plantlets from cv. Cardinal on MS $+0.12 \mathrm{mg} \mathrm{L}^{-1}$ of $\mathrm{GA}_{3}$ and cv. Desiree on MS $+0.25 \mathrm{mg} \mathrm{L}^{-1}$ of GA $_{3}$ illustrated reduced days to root initiation, developed maximum plantlet height and more node numbers, and took minimum days to transferable height of the plantlets. Although the employment of BAP in the culture media increased the average rate of multiplication to 3-6 shoots per plantlet (Quiroz et al., 2017), the combination of $\mathrm{GA}_{3}+\mathrm{NAA}$ gave better results since this integration improved the rate of multiplication in shoot tip culture by developing the plantlet height, the number of nodes on the plantlets (Nuwagira et al., 2015). However, Xhulaj and Gixhari (2018) suggested effective combination of $\mathrm{GA}_{3}+\mathrm{BAP}$ in the development of better explant at organogenesis phase. In another research, Xhulaj (2019) recorded better plantlet development in shoot height $(8.7 \mathrm{~cm})$, root length $(11.2 \mathrm{~cm})$ and node number (5.1) on $0.2 \mathrm{mg} \mathrm{L}^{-1} \mathrm{GA}_{3}+0.02 \mathrm{mg} \mathrm{L}^{-1} \mathrm{NAA}$ hormonal combinations.

It has been suggested that supplementation of MS medium by zeatin riboside (ZR) and zeatin showed better plantlet growth compared to the other cytokinin-containing media (Molla et al., 2011; Chaudhary and Mittal, 2014). Similarly, Dhital et al. (2010) suggested that integration of zeatin, $\alpha$ naphthaleneacetic acid (NAA), and $\mathrm{GA}_{3}$, in addition to BAP and $\mathrm{GA}_{3}$, might be used for direct regeneration of potato shoots under in vitro conditions. Minimum days to shoot induction (17 days) with maxiumum shoot number (12.93) and and leaf number (3.22) were recorded on $5.0 \mathrm{mg} \mathrm{L}^{-1} \mathrm{ZR}$ supplemented MS medium (Huda et al. 2013). In another study, Campos et al. (2016) used $3 \mathrm{mg} \mathrm{L}^{-1}$ concentration of ZR supplemented MS medium with different concentrations of NAA+GA 3 , and the best for shoot regeneration from potato internode explants were obtained from $0.05 \mathrm{mg} \mathrm{L}^{-1} \mathrm{NAA}+0.10$ $\mathrm{mg} \mathrm{L}^{-1} \mathrm{GA}_{3}+3 \mathrm{mg} \mathrm{L}^{-1} \mathrm{ZR}$ including MS medium. 
JA is generally well-known because of its tuber-stimulating property in vitro (Koda et al., 1991; van den Berg and Ewing, 1991) and has been associated with the promotion of senescence (Pelacho et al., 1997) in the micropropagated potatoes. However, it has been recently shown that JA has outstanding and potentially beneficial features that affect plant growth and improvement when applied exogenously to potato plantlets (Ravnikar et al., 1992; Dermastia et al., 1994). Kumlay et al. (2014) and Kumlay (2016) suggested that root formation as well as vegetative development could be stimulated on in vitro cultured potato explants by application of JA.

The purpose of this research was to determine the influence of integration of adenine type cytokinins, naphthalene type auxins, jasmonic acid and $\mathrm{GA}_{3}$ on improvement of in vitro grown potato cultivars Caspar, Granola and Pasinler-92 using meristem originated binodal stem segments as explants.

\section{MATERIALS AND METHODS}

\section{Preparation, Concentrations and Combinations of Plant Rrowth Regulators Used in the Research}

MS medium including vitamins, sucrose $[3 \%,(\mathrm{w} / \mathrm{v})]$ and agar $[0.8 \%(\mathrm{w} / \mathrm{v})]$ was used in the study. The $\mathrm{pH}$ was modulated to $5.7 \pm 0.1$ by using $1.0 \mathrm{~N} \mathrm{HCl}$ or $1.0 \mathrm{~N} \mathrm{NaOH}$ after addition of all medium constituents except agar and Ca-pantothenate. Since the combination of $\mathrm{GA}_{3}+\mathrm{NAA}$ gave better results by developing the plantlet height, the number of stems and nodes on the plantlets (Nuwagira et al., 2015), the integration of these PGRs was used as control. The stem node segments of meristem originated potato explants were regenerated on MS medium including $0.1 \mathrm{mg} \mathrm{L}^{-1} \mathrm{GA}_{3}+0.1 \mathrm{mg} \mathrm{L}^{-1} \mathrm{NAA}$ (control) with the combination of $2.0 \mathrm{mg} \mathrm{L}^{-1} \mathrm{KIN}, 2.0 \mathrm{mg} \mathrm{L}^{-1} \mathrm{BAP}, 1.0 \mathrm{mg} \mathrm{L}^{-1} \mathrm{ZR}$, and $0.5 \mathrm{mg} \mathrm{L}^{-1} \mathrm{JA}$. Because of thermolabile properties of $\mathrm{GA}_{3}, \mathrm{ZR}$ and JA hormones, they were not autoclaved but they were filtersterilized by passing through $0.22-\mu \mathrm{m}$ Millipore filters (Schleicher \& Schuell, FP 30/0.2 CA-S; 0.2 $\mu$ m; 7 bar max) inside a laminar flow cabin, and added to the autoclaved medium after cooling to $40-45^{\circ} \mathrm{C}$. The other PGRs were sterilized along with culture medium by autoclaving at $120^{\circ} \mathrm{C}, 104 \mathrm{kPa}$ for 15 min.

\section{Cultivars, Origin of Plant Material and Micropropagation of Explants in the Research}

Since in vitro grown plantlet is more reliable explants source than field grown plant material (de Morais, 2018), binodal stem explants taken from four weeks old meristem originated seedlings regenerated on micropropagated sprouts of Caspar, Granola and Pasinler-92 potato genotypes were used in the research. Binodal stem explants were aseptically incubated on the MS medium including 10 explants per replication $(n=6)$, totally 60 binodal cuttings per treatment. Explants were cultured under 2,000 lux light intensity with 16-h of long day photoperiod at a temperature of $24 \pm 2{ }^{\circ} \mathrm{C}$ for 6 weeks.

\section{Observations and Statistical Method for Evaluation the Results}

The results of experiment were recorded as days to shoot and root initiation, shoot and root length $(\mathrm{cm})$, the number of leaves, nodes, axillary shoots and roots per plantlet, fresh weight (FW) and dry weight (DW) of plantlet (mg). FW of harvested plantlets was determined as in $\mathrm{mg}$ after washing completely to remove the attached agar, sugar and salt residues from roots, and drying on soft sterile tissue paper. Plantlets were dehydrated to a stable weight at $60^{\circ} \mathrm{C}$ for $2 \mathrm{~d}$, and then DW of plantlets was determined as in mg. A completely randomized design (CRD) was employed to reveal the performance of three potato cultivars, using five PGR combinations with six replications. Results of the study were subjected to the analysis of variance, the means were evaluated by using Duncan's multiple comparison test and data presented by various letters in the same column are different statistically. Results on all parameters were expressed as means from six replications $(n=6)$ with standard error $( \pm S E)$. 


\section{RESULTS AND DISCUSSION}

The influence of PGRs on the stimulation of plantlet characteristics is presented in Tables 1 through 10. The results showed significantly $(P<0.01)$ different effects of PGRs on the length of shoots and roots, number of nodes, leaves, axillary shoots, roots per shoots along with FW and DW of the plantlets. The results indicated a significant interaction (at the $1 \%$ probability level) between PGR combinations (treatments) and cultivars potentiality for the number of leaves and nodes per explant and the length of root. Similarly, an interaction $(P<0.05)$ was also recorded between variety capability and PGRs for the mean shoot length, the mean branch number, FW and DW content of regenerating plantlets.

The days to induce shoot and root initiation ranged $4.00-15.75 \mathrm{~d}$ and $11.00-28.00 \mathrm{~d}$, respectively (Table 1). The average shoot length varied $2.70-17.25 \mathrm{~cm}$, the number of axillary shoots ranged $2.50-$ 15.25 (Table 2), the number of nodes differed 2.75-19.00, the number of leaves ranged 2.75-19.00 (Table 3), the number of roots varied 3.75-25.25, root length changed 2.45-18.45 cm (Table 4). Furthermore, the results had a clear effect on FW of plantlets with range of 186.48-809.73 mg, and the DW of the plantlets differed in range of 19.32-123.73 mg on all PGR combinations treatments. The combined use of KIN, BAP, ZR, and JA with $\mathrm{GA}_{3}$ plus NAA in $1.0 \times$ MS medium resulted in 5.0-11.5 d to induce shoots and 7.5-17.0 d to induce roots. The treatments of hormones ended up with 1.2-5.4 fold increase in shoot length, 1.7-5.8 fold increment in the number of axillary shoots, 1.5-6.9 fold higher node number, 1.3-6.3 fold rise in the number of leaves, 1.5-5.7 fold higher growth in the number of roots, 1.4-6.5 fold rise in root length, 1.3-4.2 fold increase in FW of plantlets, and 1.6-6.4 fold increase in DW of plantlets compared to single application of $\mathrm{GA}_{3}$ with NAA. The data of this research also illustrated that among the PGRs, the effect of JA was more pronounced in all the studied seedling properties compared to the PGRs. Because the single application of $\mathrm{GA}_{3}$ and NAA at a $0.1 \mathrm{mg} \mathrm{L}^{-1}$ concentration (control) showed weaker plantlet growth parameters and their number was much lower than the other PGR treatments, the lowest results from each character were not be discussed in detail in text. The data from of each application and their interactions with cultivar are presented below under different subheadings.

\section{Days to Shoot Initiation}

The influence of all hormone treatments on days to shoot initiation varied significantly $(P<0.01)$. The minimum days to shoot initiation were recorded on Pasinler-92 (4.00 d), followed by Granola (4.75 d) and Caspar (5.50 d) on MS medium including $0.1 \mathrm{mg} \mathrm{L}^{-1} \mathrm{GA}_{3}+0.1 \mathrm{mg} \mathrm{L}^{-1} \mathrm{NAA}+0.5 \mathrm{mg} \mathrm{L}^{-1} \mathrm{JA}$ after 6 weeks of cultivation. However, late-maturing Caspar had the most slowed shoot initiation period of $15.75 \mathrm{~d}$, followed by 14.25 on Granola, and $13.75 \mathrm{~d}$ on Pasinler-92 on control treatment (Table 1). The results displayed that the PGR applications were efficient to shorten days to shoot initiation compared to regeneration on control medium. Single application of $\mathrm{GA}_{3}$ and NAA or in combination with any of the adenine type cytokinin did not significantly reduced days to shoot initiation.

The results are in partial agreement with Zhang and Cheng (1996) who recorded significant consequences of JA on in vitro-grown potato nodal explants in terms of shoot induction. In another study, it has been illustrated that days to shoot appearance started 11.75 days earlier on MS medium including $2 \mu \mathrm{M}$ JA compared to the controls (Kumlay, 2016).

\section{Days to Root Initiation}

Significant differences were noted among PGR treatments on the number of days to root initiation $(P<0.01)$. The treatment with KIN, BAP, ZR and JA had a meaningful influence in lowering the days to root initiation compared to regeneration on control medium. Single application of $\mathrm{GA}_{3}$ and NAA or 
in combination with any of the adenine type cytokinin did not significantly reduced days to root induction.

Table 1. Effects of various PGR combinations on the days to shoot initiation

\begin{tabular}{|c|c|c|c|c|c|c|c|c|}
\hline \multicolumn{6}{|c|}{ PGR Combinations $\left(\mathrm{mg} \mathrm{L}^{-1}\right)$} & \multicolumn{3}{|c|}{ Days to Shoot Initiation } \\
\hline $\mathrm{GA}_{3}$ & NAA & KIN & BAP & $\mathrm{ZR}$ & JA & Pasinler-92 & Granola & Caspar \\
\hline 0.1 & 0.1 & \multicolumn{4}{|c|}{ Control } & $13.75 \pm 0.65 \mathrm{e}$ & $14.25 \pm 1.75 \mathrm{~d}$ & $15.75 \pm 1.75 \mathrm{~d}$ \\
\hline 0.1 & 0.1 & 2.0 & & & & $10.75 \pm 1.11 d$ & $9.50 \pm 0.48 \mathrm{c}$ & $9.25 \pm 0.48 \mathrm{c}$ \\
\hline 0.1 & 0.1 & & 2.0 & & & $8.50 \pm 0.87 \mathrm{c}$ & $8.00 \pm 0.41 b c$ & $8.75 \pm 0.48 b c$ \\
\hline 0.1 & 0.1 & & & 1.0 & & $6.25 \pm 0.25 b$ & $7.50 \pm 0.64 b$ & $8.00 \pm 0.58 b$ \\
\hline 0.1 & 0.1 & & & & 0.5 & $4.00 \pm 0.25 \mathrm{a}$ & $4.75 \pm 0.25 \mathrm{a}$ & $5.50 \pm 0.41 \mathrm{a}$ \\
\hline
\end{tabular}

Average values presented by various letters in the same column are statistically different

Table 2. Effects of various PGR combinations on the days to root initiation

\begin{tabular}{|c|c|c|c|c|c|c|c|c|}
\hline \multicolumn{6}{|c|}{ PGR Combinations $\left(\mathrm{mg} \mathrm{L}^{-1}\right)$} & \multicolumn{3}{|c|}{ Days to Root Initiation } \\
\hline $\mathrm{GA}_{3}$ & NAA & KIN & BAP & ZR & JA & Pasinler-92 & Granola & Caspar \\
\hline 0.1 & 0.1 & \multicolumn{4}{|c|}{ Control } & $22.75 \pm 0.48 \mathrm{e}$ & $24.50 \pm 0.82 \mathrm{e}$ & $28.00 \pm 0.82 \mathrm{e}$ \\
\hline 0.1 & 0.1 & 2.0 & & & & $17.25 \pm 1.11 \mathrm{~d}$ & $18.75 \pm 0.25 \mathrm{~d}$ & $20.50 \pm 0.29 d$ \\
\hline 0.1 & 0.1 & & 2.0 & & & $15.00 \pm 0.57 \mathrm{c}$ & $16.50 \pm 1.00 \mathrm{c}$ & $18.00 \pm 0.82 \mathrm{c}$ \\
\hline 0.1 & 0.1 & & & 1.0 & & $13.00 \pm 0.50 \mathrm{~b}$ & $14.25 \pm 0.25 b$ & $15.50 \pm 0.96 b$ \\
\hline 0.1 & 0.1 & & & & 0.5 & $11.00 \pm 0.63 \mathrm{a}$ & $12.00 \pm 0.50 \mathrm{a}$ & $12.50 \pm 0.48 \mathrm{a}$ \\
\hline
\end{tabular}

Average values presented by various letters in the same column are statistically different

It can be seen on Table 2 that the minimum days required for root initiation were recorded on MS medium supplemented with $0.1 \mathrm{mg} \mathrm{L}^{-1} \mathrm{GA}_{3}+0.1 \mathrm{mg} \mathrm{L}^{-1} \mathrm{NAA}+0.5 \mathrm{mg} \mathrm{L}^{-1} \mathrm{JA}(11.00 \mathrm{~d}$ for Pasinler92, 12.00 for Granola, and 12.50 for Caspar). Although there are no many studies of JA supplemented medium regarding days to root induction; in a previous study, involvement of $2 \mu \mathrm{M}$ JA to MS medium of micropropagated potato plantlets stimulated the improvement of roots 17.75 days earlier compared to the control (Kumlay, 2016).

\section{Average Shoot Length per Plantlet (cm)}

Elongation of regenerated shoots plays important roles in the initial growth stage: It facilitates easy distinction between fast- and slow-regenerating cultivars. It also helps researcher to easily distinguish cultivars with elongating shoots and fast regenerating nodes per explant (Kovac and Ravnikar, 1994).

Combinations of $\mathrm{GA}_{3}+\mathrm{NAA}$ together with KIN, BAP, ZR, and JA affected the length of shoots, demonstrating significant differences among them $(P<0.01)$. Reduced shoot length was noted on MS medium including only $\mathrm{GA}_{3}+\mathrm{NAA}$. Single application of $\mathrm{GA}_{3}$ and NAA or in combination with any of the adenine type cytokinin did not significantly improved shoot length (Table 3 ). The interaction between cultivars and PGR treatments also illustrated noteworthy differences $(P<0.01)$. Among the five PGRs treatments, a considerable increase was determined using $\mathrm{GA}_{3}+\mathrm{NAA}+\mathrm{JA}$; the longest shoots were observed in the Caspar $(17.25 \mathrm{~cm})$, proceeded by Granola $(15.88 \mathrm{~cm})$ and Pasinler-92 $(15.18 \mathrm{~cm})$ using MS medium including $0.1 \mathrm{mg} \mathrm{L}^{-1} \mathrm{GA}_{3}+0.1 \mathrm{mg} \mathrm{L}^{-1} \mathrm{NAA}+0.5 \mathrm{mg} \mathrm{L}^{-1} \mathrm{JA}$ after 6 weeks of cultivation (Table 3).

Irrespective of PGR combinations, MS medium containing JA showed significantly improved shoot length. The outcomes of the present experiment are in consensus with the findings of Dermastia et al. (1994), who revealed that plantlets grown in a medium supplemented with JA were taller when compared to the other PGR treatments. Zhang and Cheng (1996) noted potato cultivars exhibited various 
responses to JA in shoot development when subjected to different JA concentrations in the MS medium. Pelacho et al. (1997) revealed that the application of $0.1 \mathrm{mg} \mathrm{L}^{-1} \mathrm{JA}$ increased the length shoot to 15.65 $\mathrm{cm}$, however shoot elongation decreased to $10.56 \mathrm{~cm}$ on $1 \mathrm{mg} \mathrm{L}^{-1} \mathrm{JA}$ including MS medium. Zhang et al. (2006) obtained $8.83 \mathrm{~cm}$-long shoots from cv. Helanwuhua on $2.0 \mathrm{mg} \mathrm{L}^{-1} \mathrm{JA}$ comprising culture medium. Kumlay (2016) obtained 5.67-times longer shoots on $1.0 \mu \mathrm{M}$ JA including medium in comparison with control treatment.

Table 3. Effects of various PGR combinations on average shoot length per plantlet

\begin{tabular}{|c|c|c|c|c|c|c|c|c|}
\hline \multicolumn{6}{|c|}{ PGR Combinations $\left(\mathrm{mg} \mathrm{L}^{-1}\right)$} & \multicolumn{3}{|c|}{ Shoot Length $(\mathrm{cm})$} \\
\hline $\mathrm{GA}_{3}$ & NAA & KIN & BAP & ZR & JA & Pasinler-92 & Granola & Caspar \\
\hline 0.1 & 0.1 & \multicolumn{4}{|c|}{ Control } & $2.70 \pm 0.45 \mathrm{~d}$ & $4.23 \pm 0.62 \mathrm{~d}$ & $3.38 \pm 0.41 \mathrm{~d}$ \\
\hline 0.1 & 0.1 & 2.0 & & & & $7.15 \pm 0.98 \mathrm{c}$ & $5.98 \pm 0.60 \mathrm{~d}$ & $6.50 \pm 0.47 \mathrm{c}$ \\
\hline 0.1 & 0.1 & & 2.0 & & & $10.10 \pm 0.77 b$ & $8.60 \pm 0.67 \mathrm{c}$ & $7.85 \pm 0.52 \mathrm{c}$ \\
\hline 0.1 & 0.1 & & & 1.0 & & $10.63 \pm 0.33 b$ & $11.80 \pm 0.25 b$ & $11.58 \pm 0.54 b$ \\
\hline 0.1 & 0.1 & & & & 0.5 & $15.18 \pm 0.78 \mathrm{a}$ & $15.88 \pm 0.84 \mathrm{a}$ & $17.25 \pm 0.35 \mathrm{a}$ \\
\hline
\end{tabular}

Average values presented by various letters in the same column are statistically different

\section{Average Number of Axillary Shoots per Plantlet}

Since the increased number of axillary shoots could be multiplied easily for further shoot multiplication, the number of axillary shoots per plantlet is a significant parameter when studying the growth rate of explants. Significant differences were determined among PGRs $(P<0.01)$, since variants of KIN, BAP, ZR, and JA affected the number of axillary shoots. The interaction between cultivars and PGR treatments demonstrated meaningful differences statistically $(P<0.05)$. The highest quantity of axillary shoots was obtained in Caspar (15.25) pursued by Pasinler-92 (13.00) and Granola (12.00) using MS medium supplemented with $0.1 \mathrm{mg} \mathrm{L}^{-1} \mathrm{GA}_{3}+0.1 \mathrm{mg} \mathrm{L}^{-1} \mathrm{NAA}+0.5 \mathrm{mg} \mathrm{L}^{-1} \mathrm{JA}$ combination (Table 4). Reduced number of axillary shoots was noticed on control application. Single application of $\mathrm{GA}_{3}+\mathrm{NAA}$ or in combination with any of the adenine type cytokinin did not significantly improve the quantity of axillary stems per plantlet.

Table 4. Effects of various PGR combinations on average number of axillary shoots per plantlet

\begin{tabular}{|c|c|c|c|c|c|c|c|c|}
\hline \multicolumn{6}{|c|}{ PGR Combinations $\left(\mathrm{mg} \mathrm{L}^{-1}\right)$} & \multicolumn{3}{|c|}{ Number of Axillary Shoots } \\
\hline $\mathrm{GA}_{3}$ & NAA & KIN & BAP & ZR & JA & Pasinler-92 & Granola & Caspar \\
\hline 0.1 & 0.1 & \multicolumn{4}{|c|}{ Control } & $2.50 \pm 0.29 \mathrm{c}$ & $3.25 \pm 0.25 \mathrm{~d}$ & $2.75 \pm 0.25 \mathrm{~d}$ \\
\hline 0.1 & 0.1 & 2.0 & & & & $7.75 \pm 0.32 b$ & $7.50 \pm 0.29 \mathrm{c}$ & $6.75 \pm 0.48 \mathrm{c}$ \\
\hline 0.1 & 0.1 & & 2.0 & & & $8.25 \pm 0.48 b$ & $6.50 \pm 0.29 \mathrm{~cd}$ & $6.50 \pm 0.29 \mathrm{c}$ \\
\hline 0.1 & 0.1 & & & 1.0 & & $8.75 \pm 0.48 b$ & $8.75 \pm 0.25 b$ & $9.00 \pm 0.41 \mathrm{~b}$ \\
\hline 0.1 & 0.1 & & & & 0.5 & $13.00 \pm 0.41 \mathrm{a}$ & $12.00 \pm 0.41 \mathrm{a}$ & $15.25 \pm 0.41 \mathrm{a}$ \\
\hline
\end{tabular}

Average values presented by various letters in the same column are statistically different

The data of the current research are in partial harmony with Ravnikar et al. (1992), Zhang and Cheng (1996) and Kumlay (2016). Ravnikar et al. (1992) expressed that the inclusion of JA at lower concentrations $(0.1-1.0 \mu \mathrm{M})$ on MS medium resulted in the emergence of lateral branches. Zhang and Cheng (1996) suggested that the quantity of lateral branches enhanced significantly depending on low JA concentrations $(0.1-5 \mu \mathrm{M})$. Kumlay (2016) obtained 4.57 times higher lateral shoots totally and a maximum number of 8.00 branches from Caspar by addition of $1.0 \mu \mathrm{M}$ JA to MS medium compared to the control. 
The results were not similar to the findings of Rabbani et al. (2001), Hussain et al. (2005), and Uddin (2006). Rabbani et al. (2001) determined that $2.0 \mathrm{mg} \mathrm{L}^{-1} \mathrm{BAP}+\mathrm{GA}_{3}$ containing MS medium could bring significant development on the in vitro multiple shoot induction by increasing the number axillary shoots. Hussain et al. (2005) reported the highest number of 9.0-shoot in cv. Altamash, and 14.3 shoots in cv. Diamond using nodal cuttings on $2.0 \mathrm{mg} \mathrm{L}^{-1}$ of BAP including MS medium. Uddin (2006) regenerated the better results with the combination of $3.0 \mathrm{mg} \mathrm{L}^{-1} \mathrm{BAP}+2.0 \mathrm{mg} \mathrm{L}^{-1} \mathrm{KIN}$ comprised medium, and emphasized this application was superior to using BAP or KIN alone for multiple shoot induction (2.0 shoots).

\section{Average Number of Nodes per Plantlet}

The number of nodes per binodal explants was affected by PGR applications significantly $(P<0.01)$. Variations among potato varieties were also significant statistically $(P<0.05)$. The presented results clearly indicate role of $\mathrm{GA}_{3}$, NAA, and JA in inducing multiple nodes. Maximum number of nodes was determined in Caspar (19.00), proceeded by Granola (16.75) and Pasinler-92 (12.00) on 0.1 $\mathrm{mg} \mathrm{L}^{-1} \mathrm{GA}_{3}+0.1 \mathrm{mg} \mathrm{L}^{-1} \mathrm{NAA}+0.5 \mathrm{mg} \mathrm{L}^{-1} \mathrm{JA}$ including MS medium (Table 5). Reduced number of nodes was noted on control medium. Single application of $\mathrm{GA}_{3}$ and NAA or in combination with any of the adenine type cytokinin did not significantly improve number of nodes per explant.

The introduced findings are development over previous studies by Rabbani et al. (2001), and Uddin (2006). Rabbani et al. (2001) obtained the highest number of nodes (6.2) using $4.0 \mathrm{mg} \mathrm{L}^{-1} \mathrm{GA}_{3}$ singly. Contrary to the results shown in this study, Uddin (2006) observed a better regeneration response using BAP compared to KIN. The results are in harmony with the findings of Ravnikar et al. (1990), Zhang and Cheng (1996) and Kumlay (2016) in which they recorded that JA concentration used variably showed a rise on node number per plantlet.

Table 5. Effects of various PGR combinations on average node number per plantlet

\begin{tabular}{|c|c|c|c|c|c|c|c|c|}
\hline \multicolumn{6}{|c|}{ PGR Combinations (mg L $\left.{ }^{-1}\right)$} & \multicolumn{3}{|c|}{ Number of Nodes } \\
\hline $\mathrm{GA}_{3}$ & NAA & KIN & BAP & ZR & JA & Pasinler-92 & Granola & Caspar \\
\hline 0.1 & 0.1 & \multicolumn{4}{|c|}{ Control } & $3.00 \pm 0.41 \mathrm{c}$ & $4.25 \pm 0.63 \mathrm{c}$ & $2.75 \pm 0.25 \mathrm{c}$ \\
\hline 0.1 & 0.1 & 2.0 & & & & $7.25 \pm 0.51 b$ & $6.50 \pm 0.29 \mathrm{~b}$ & $5.25 \pm 0.75 b$ \\
\hline 0.1 & 0.1 & & 2.0 & & & $6.00 \pm 0.71 \mathrm{~b}$ & $6.75 \pm 0.48 b$ & $6.75 \pm 0.25 b$ \\
\hline 0.1 & 0.1 & & & 1.0 & & $7.50 \pm 0.64 b$ & $6.25 \pm 0.25 b$ & $6.50 \pm 0.50 \mathrm{~b}$ \\
\hline 0.1 & 0.1 & & & & 0.5 & $12.00 \pm 0.41 \mathrm{a}$ & $16.75 \pm 0.63 \mathrm{a}$ & $19.00 \pm 0.58 \mathrm{a}$ \\
\hline
\end{tabular}

Average values presented by various letters in the same column are statistically different

\section{Average Number of Leaves per Plantlet}

The number of leaves per plantlet demonstrated noteworthy differences $(P<0.01)$ after treatment with PGRs used in this research. The maximum number of leaves was detected in Caspar (19.00), succeeded by Pasinler-92 (15.50) and Granola (15.25) using MS medium supplemented with $0.1 \mathrm{mg} \mathrm{L}^{-}$ ${ }^{1} \mathrm{GA}_{3}+0.1 \mathrm{mg} \mathrm{L}^{-1} \mathrm{NAA}+0.5 \mathrm{mg} \mathrm{L}^{-1} \mathrm{JA}$ (Table 6). Reduced number of leaves was noted on control medium. Single application of $\mathrm{GA}_{3}$ and NAA or in combination with any of the adenine type cytokinin did not significantly improved number of leaves per explant.

The findings of the research have edge over all former studies with more number of leaves per explant emphasizing role of NAA, $\mathrm{GA}_{3}$ and JA used in combination to induce leaves on regenerating plantlets. Dermastia et al. (1997) demonstrated that explants cultured on JA supplemented medium resulted in expanded leaves. Kumlay (2016) observed an increase on leaf number from Caspar (19.00), on $1.0 \mu \mathrm{M}$ JA including medium, and emphasized that the addition of JA concluded in a 7.60-times rise in the leaf number compared to no PGRs including control medium. 
Table 6. Effects of various PGR combinations on the average number of leaves per plantlet

\begin{tabular}{|c|c|c|c|c|c|c|c|c|}
\hline \multicolumn{6}{|c|}{ PGR Combinations $\left(\mathrm{mg} \mathrm{L}^{-1}\right)$} & \multicolumn{3}{|c|}{ Number of Leaves } \\
\hline $\mathrm{GA}_{3}$ & NAA & KIN & BAP & ZR & JA & Pasinler-92 & Granola & Caspar \\
\hline 0.1 & 0.1 & \multicolumn{4}{|c|}{ Control } & $2.75 \pm 0.48 \mathrm{c}$ & $3.50 \pm 0.29 \mathrm{~d}$ & $3.00 \pm 0.00 \mathrm{c}$ \\
\hline 0.1 & 0.1 & 2.0 & & & & $7.25 \pm 0.68 b$ & $6.25 \pm 0.25 b$ & $4.50 \pm 0.29 c$ \\
\hline 0.1 & 0.1 & & 2.0 & & & $3.75 \pm 0.25 \mathrm{c}$ & $5.00 \pm 0.41 \mathrm{c}$ & $3.75 \pm 0.48 \mathrm{c}$ \\
\hline 0.1 & 0.1 & & & 1.0 & & $7.50 \pm 1.26 \mathrm{~b}$ & $3.25 \pm 0.25 \mathrm{~d}$ & $10.50 \pm 0.65 b$ \\
\hline 0.1 & 0.1 & & & & 0.5 & $15.50 \pm 0.65 \mathrm{a}$ & $15.25 \pm 0.63 \mathrm{a}$ & $19.00 \pm 1.22 \mathrm{a}$ \\
\hline
\end{tabular}

Average values presented by various letters in the same column are statistically different

\section{Average Number of Roots per Plantlet}

Data obtained from this research showed significant influence of all PGR treatments on root number $(P<0.01)$. Single application of $\mathrm{GA}_{3}$ and NAA or in combination with any of the adenine type cytokinin did not significantly improve number of roots per explant. The roots of the plantlets treated with the application of $\mathrm{GA}_{3}$ and NAA at a $0.1 \mathrm{mg} \mathrm{L}^{-1}$ or any concentration of adenine type cytokinin were much weaker and their number was much lower than compared to JA containing treatments. The maximum number of roots were recorded in Caspar (25.25), succeeded by Granola (24.00) and Pasinler92 (23.75) using MS medium containing $0.1 \mathrm{mg} \mathrm{L}^{-1} \mathrm{GA}_{3}+0.1 \mathrm{mg} \mathrm{L}^{-1} \mathrm{NAA}+0.5 \mathrm{mg} \mathrm{L}^{-1} \mathrm{JA}$ (Table 7). The results of this study showed edge of NAA, $\mathrm{GA}_{3}$, JA regenerated shoots to induce higher number of roots and enhanced rooting efficiency indicate that the NAA, GA 3 , JA-supplemented medium prepares plantlets for easy acclimatization to ex vitro conditions and increases their chance to survival under greenhouse conditions.

Table 7. Effects of various PGR combinations on the average number of roots

\begin{tabular}{|c|c|c|c|c|c|c|c|c|}
\hline \multicolumn{6}{|c|}{ PGR Combinations $\left(\mathrm{mg} \mathrm{L}^{-1}\right)$} & \multicolumn{3}{|c|}{ Number of Roots } \\
\hline $\mathrm{GA}_{3}$ & NAA & KIN & BAP & ZR & JA & Pasinler-92 & Granola & Caspar \\
\hline 0.1 & 0.1 & \multicolumn{4}{|c|}{ Control } & $3.75 \pm 0.25 \mathrm{e}$ & $5.50 \pm 0.65 \mathrm{e}$ & $4.00 \pm 0.87 \mathrm{e}$ \\
\hline 0.1 & 0.1 & 2.0 & & & & $9.75 \pm 1.00 \mathrm{~d}$ & $10.25 \pm 0.48 \mathrm{~d}$ & $9.50 \pm 0.65 \mathrm{~d}$ \\
\hline 0.1 & 0.1 & & 2.0 & & & $15.50 \pm 0.29 \mathrm{c}$ & $14.75 \pm 0.25 c$ & $15.25 \pm 0.48 \mathrm{c}$ \\
\hline 0.1 & 0.1 & & & 1.0 & & $18.00 \pm 0.82 b$ & $18.50 \pm 0.87 \mathrm{~b}$ & $18.00 \pm 0.41 b$ \\
\hline 0.1 & 0.1 & & & & 0.5 & $23.75 \pm 0.48 \mathrm{a}$ & $24.00 \pm 0.41 \mathrm{a}$ & $25.25 \pm 0.48 \mathrm{a}$ \\
\hline
\end{tabular}

Average values presented by various letters in the same column are statistically different

The results reported here are improvement over previous studies. Ravnikar et al. (1990) noted the highest root number on higher JA including MS medium, although its roots shortened and its diameter increased. Kovac and Ravnikar (1994) reported that 1.0 $\mu \mathrm{M}$ JA concentration improved the root systems of potatoes grown in vitro. Martin-Closas et al. (2000) implied that JA induced root establishment in in vitro cultured potato explants. Although Pelacho et al. (1997) obtained the highest number of 14.8 roots on $1.0 \mathrm{mg} \mathrm{L}^{-1} \mathrm{JA}$ including medium, and Zhang et al. (2006) determined the highest number of 12.00 roots in cv. Helanwuhua on $2.0 \mathrm{mg} \mathrm{L}^{-1} \mathrm{JA}$ containing MS medium. Kumlay (2016) pointed out that the inclusion of JA showed a 4.69-times higher root number. It is clear from these results that when the concentrations increased the number of roots decreased or did not increase significantly.

\section{Average Root Length per Plantlet (cm)}

The treatment of PGRs varied the length of roots significantly $(P<0.01)$ among potato cultivars. The longest roots were determined from Pasinler-92 $(18.45 \mathrm{~cm})$, followed by Caspar $(17.10 \mathrm{~cm})$ and Granola $\left(17.03 \mathrm{~cm}\right.$ ) using control medium $+0.5 \mathrm{mg} \mathrm{L}^{-1} \mathrm{JA}$ (Table 8 ) without having any adverse effect 
on texture of roots. Irrespective of the cultivar, the developing roots were morphologically strong did not show any abnormality or inhibition, branched and had tendency to grow with the passage of time. The results clearly demonstrate that presence of $\mathrm{GA}_{3}+\mathrm{NAA}+\mathrm{JA}$ in one medium significantly improve root length in potato cultivars. Single application of $\mathrm{GA}_{3}$ and NAA or in combination with any of the adenine type cytokinin did not significantly improve root length.

There are contradictory results and no agreement about JA containing medium in previous studies. Ravnikar et al. (1992) illustrated that JA treatment using lower concentrations $(0.1-1.0 \mu \mathrm{M})$ resulted in a very distinction root structure with many irregular branches. Dermastia et al. (1994) demonstrated that explants cultures in JA containing medium generated a well-developed root system. Although Pelacho et al. (1997) obtained the increased the length of root on $1.0 \mathrm{mg} \mathrm{L}^{-1} \mathrm{JA}$ including medium $(14.8 \mathrm{~cm})$, Zhang et al. (2006) illustrated that the application $2 \mathrm{mg} \mathrm{L}^{-1} \mathrm{JA}$ including medium significantly increased root length $(16.37 \mathrm{~cm}$ in cv. Favorita), and Kumlay (2016) determined the longest roots from cv. Pasinler-92 $(14.95 \mathrm{~cm})$, including $1.0 \mu \mathrm{M} \mathrm{JA}$ containing medium. The findings of the current research are in disagreement with the results of Vilhar et al. (1997), which showed that JA changed the root structure and inhibited root proliferation, but caused thicker roots through cell division and not cell enlargement.

Table 8. Effects of various PGR combinations on the average root length

\begin{tabular}{|c|c|c|c|c|c|c|c|c|}
\hline \multicolumn{6}{|c|}{ PGR Combinations $\left(\mathrm{mg} \mathrm{L}^{-1}\right)$} & \multicolumn{3}{|c|}{ Root Length (cm) } \\
\hline $\mathrm{GA}_{3}$ & NAA & KIN & BAP & $\mathrm{ZR}$ & JA & Pasinler-92 & Granola & Caspar \\
\hline 0.1 & 0.1 & \multicolumn{4}{|c|}{ Control } & $2.45 \pm 0.35 \mathrm{~d}$ & $4.85 \pm 0.55 \mathrm{~d}$ & $3.63 \pm 0.36 \mathrm{e}$ \\
\hline 0.1 & 0.1 & 2.0 & & & & $7.28 \pm 0.38 \mathrm{c}$ & $5.95 \pm 0.48 \mathrm{~cd}$ & $6.20 \pm 0.45 \mathrm{~d}$ \\
\hline 0.1 & 0.1 & & 2.0 & & & $8.78 \pm 0.53 c$ & $6.50 \pm 0.44 c$ & $7.68 \pm 0.59 \mathrm{c}$ \\
\hline 0.1 & 0.1 & & & 1.0 & & $11.03 \pm 0.65 b$ & $10.25 \pm 0.48 b$ & $10.35 \pm 0.27 b$ \\
\hline 0.1 & 0.1 & & & & 0.5 & $18.45 \pm 0.59 a$ & $17.03 \pm 0.68 \mathrm{a}$ & $17.10 \pm 0.36 \mathrm{a}$ \\
\hline
\end{tabular}

Average values presented by various letters in the same column are statistically different

\section{Average Fresh Weight per Plantlet (mg)}

The application of PGRs to the MS medium influenced the FW of cultured explants significantly $(P<0.01)$ among cultivars. The interaction of PGRs and potato cultivars on the FW of plantlets illustrated significant differences $(P<0.05)$. The heaviest FW of cultured explants was observed in Granola (404.87 $\mathrm{mg}$ ), followed by Pasinler-92 (399.68 mg) and Caspar (390.08 mg) using MS medium containing control+0.5 mg L-1 JA (Table 5). However, the minimum FW of plantlets was observed in cv. Caspar (93.24 mg) and cv. Pasinler-92 (94.23 mg) using MS medium containing control application (Table 9). These results clearly show that presence of $\mathrm{GA}_{3}+\mathrm{NAA}+\mathrm{JA}$ in one medium significantly improve fresh weight in potato cultivars.

Table 9. Effects of various PGR combinations on the average fresh weight of plantlets

\begin{tabular}{|c|c|c|c|c|c|c|c|c|}
\hline \multicolumn{6}{|c|}{ PGR Combinations $\left(\mathrm{mg} \mathrm{L}^{-1}\right)$} & \multicolumn{3}{|c|}{ Fresh Weight of Plantlet (mg) } \\
\hline $\mathrm{GA}_{3}$ & NAA & KIN & BAP & ZR & JA & Pasinler-92 & Granola & Caspar \\
\hline 0.1 & 0.1 & \multicolumn{4}{|c|}{ Control } & $94.23 \pm 6.9 \mathrm{~d}$ & $108.57 \pm 6.3 \mathrm{~d}$ & $93.24 \pm 4.3 \mathrm{~d}$ \\
\hline 0.1 & 0.1 & 2.0 & & & & $205.30 \pm 9.7 \mathrm{c}$ & $185.62 \pm 10.0 \mathrm{c}$ & $195.73 \pm 12.0 \mathrm{c}$ \\
\hline 0.1 & 0.1 & & 2.0 & & & $208.02 \pm 6.5 c$ & $139.34 \pm 14.5 d$ & $153.84 \pm 16.9 \mathrm{c}$ \\
\hline 0.1 & 0.1 & & & 1.0 & & $317.07 \pm 13.8 b$ & $298.78 \pm 20.8 b$ & $331.95 \pm 17.2 b$ \\
\hline 0.1 & 0.1 & & & & 0.5 & $399.68 \pm 16.9 \mathrm{a}$ & $404.87 \pm 16.8 \mathrm{a}$ & $390.08 \pm 27.4 \mathrm{a}$ \\
\hline
\end{tabular}

Average values presented by various letters in the same column are statistically different 
The current findings are in partial harmony with previous studies, all of which used variable concentrations of JA on variable cultivars to induce maximum fresh weight. Pelacho et al. (1997) showed that increasing JA concentration decreased total FW of plantlet. Zhang et al. (2006) reported that the fresh mass of potato plantlets cultured in vitro significantly increased with application of JA, but higher amount of JA applications delayed the FW of cultured potato plantlets. Findings of Kumlay (2016) are in agreement with above researches that pointed out the maximum FW was obtained on cv. Pasinler of $649.38 \mathrm{mg}$ on $1.0 \mu \mathrm{M} \mathrm{JA}$, but same cultivar gave $418.1 \mathrm{mg}$ on $2.0 \mu \mathrm{M}$ JA containing MS medium.

\section{Average Dry Weight per Plantlet (mg)}

The influence of all PGR treatments on the DW of cultured explants varied significantly $(P<0.01)$. Variations among potato varieties, and the interaction of PGRs and varieties on the DW of plantlets also indicated significant differences at the $5 \%$ probability level. The highest DW were observed in Granola (61.85 mg), followed by Pasinler-92 (59.68 mg) and Caspar (57.15 mg) using MS medium including control+0.5 mg L $\mathrm{m}^{-1} \mathrm{JA}$. The results clearly indicate that presence of JA in MS medium significantly improved DW of cultured explants. However, the lowest DW content of plantlets was observed in Pasinler-92 (19.32 mg) using control medium, as well as in Caspar (10.17 mg) and Granola (11.98 mg) using $0.1 \mathrm{mg} \mathrm{L}^{-1} \mathrm{GA}_{3}+2 \mathrm{mg} \mathrm{L}^{-1}$ BAP containing MS medium (Table 10).

Table 10. Effects of various PGR combinations on the average dry weight of plantlets

\begin{tabular}{|c|c|c|c|c|c|c|c|c|}
\hline \multicolumn{6}{|c|}{ PGR Combinations ( $\mathrm{mg} \mathrm{L}^{-1}$ ) } & \multicolumn{3}{|c|}{ Dry Weight of Plantlet (mg) } \\
\hline $\mathrm{GA}_{3}$ & NAA & KIN & BAP & ZR & JA & Pasinler-92 & Granola & Caspar \\
\hline 0.1 & 0.1 & \multicolumn{4}{|c|}{ Control } & $9.66 \pm 0.39 \mathrm{c}$ & $11.98 \pm 0.96 b$ & $10.17 \pm 0.50 \mathrm{c}$ \\
\hline 0.1 & 0.1 & 2.0 & & & & $22.54 \pm 0.97 b c$ & $19.83 \pm 0.76 b$ & $24.76 \pm 0.73 b$ \\
\hline 0.1 & 0.1 & & 2.0 & & & $20.91 \pm 0.79 c$ & $15.05 \pm 0.50 \mathrm{~b}$ & $16.08 \pm 0.53 \mathrm{c}$ \\
\hline 0.1 & 0.1 & & & 1.0 & & $38.37 \pm 1.08 b$ & $35.35 \pm 0.96 b$ & $47.14 \pm 1.16 \mathrm{a}$ \\
\hline 0.1 & 0.1 & & & & 0.5 & $59.68 \pm 1.66 \mathrm{a}$ & $61.85 \pm 1.74 a$ & $57.15 \pm 1.87 \mathrm{a}$ \\
\hline
\end{tabular}

Average values presented by various letters in the same column are statistically different

The present findings are in agreement with previous studies by Castro et al. (2000) reported that JA significantly increased DW when compared to control treatment in the presence of $\mathrm{GA}_{3}$. MartinClosas et al. (2000) also suggested that inclusion of JA increased the mean DW of shoots (60\%) and average DW of roots $(300 \%)$ of cultured potato explants in vitro. It is also presented that, although inclusion of JA increased DW at $1.0 \mu \mathrm{M}$ concentration, the addition of $2.0 \mu \mathrm{M}$ JA decreased DW of micropropagated potato plantlets (Kumlay, 2016).

\section{CONCLUSION}

All studied cultivars responded positively to PGRs supplemented to MS medium resulting in healthy in vitro grown plantlets with green leaves and normal morphological traits. The results of this study revealed that irrespective of the parameter studied, presence of JA in one medium had significantly positive impact on potato cultivars used in this study compared to the results reported in previous researches. Since the exogenous addition of JA in combination with GA $3+$ NAA effectively reduces propagation interval and increases the number of cultured potato explants under in vitro conditions, it can be concluded that this PGR combination plays a significant role in governing shoot and root improvement on micropropagated plantlets.

Because this study has shown the influence of different hormones on cultured explants properties differed with the cultivar and the appropriate PGR concentration may be unique for each potato cultivar, further researches might be conducted to determine the optimal PGR combinations for new improved 
promising potato clones or lines. The studies could also be further expanded by investigating the factors that affect acclimatization to ex vitro conditions and microtuberization in micropropagated potato plantlets.

\section{Conflict of Interest}

The article authors declare that there is no conflict of interest between them.

\section{Author's Contiibutions}

The authors declare that they have contributed equally to the article.

\section{REFERENCES}

Campos NA, da Silva GJ, de Paula MFB, Rodrigues TB, Rodrigues LAZ, Paiva LV, 2016. A Direct Organogenesis Protocol from Shoot Segments of Solanum tuberosum cv. Monalisa. Australian Journal of Crop Science, 10 (7): 964-968.

Castro G, Abdala G, Agüero C, Tzio R, 2000. Interaction Between Jasmonic and Gibberellic Acids on in vitro Tuberization of Potato Plantlets. Potato Research, 43 (1): 83-88.

Chaudhary B, Mittal P, 2014. The Effects of Different Concentrations and Combinations of Growth Regulators on the Micropropagation of Potato (Solanum tuberosum). International Journal of Education and Science Research, 1 (4): 65-70.

de Morais TP, Asmar SA, Silva HFJ, Luz JMQ, de Melo B, 2018. Application of Tissue Culture Techniques in Potato. Bioscience Journal, 34 (4): 952-969.

Dermastia M, Ravnikar M, Vilhar B, Kovac M, 1994. Increased Level of Cytokinin Ribosides in Jasmonic Acid-Treated Potato (Solanum tuberosum) Stem Node Cultures. Physiologia Plantarum, 92 (2): 241-246.

Dhital SP, Lim HT, Manandhar HK, 2010. Direct and Efficient Plant Regeneration from Different Explant Sources of Potato Cultivars as Influenced by Plant Growth Regulators. Nepal Journal of Science and Technology, 12: 1-6.

Ghaffoor A, Shah GB, Waseem K, 2003. In vitro Response of Potato (Solanum tuberosum L.) to Various Growth Regulators. Biotechnology, 2 (3): 191-197.

Huda MS, Hossain MM, Zakaria M, Haq MZ, Hannan A, 2013. Effect of Different Explant and Concentration of Zeatine Riboside for in vitro Regeneration of Potato. Eco-Friendly Agricultural Journal, 6 (7): 128-130.

Hussain I, Muhammad A, Chaudhry Z, Asghar R, Naqvi SMS, Rashid H, 2005. Morphogenetic Potential of Three Potato (Solanum tuberosum) Cultivars from Diverse Explants, A Prerequisite in Genetic Manipulation. Pakistan Journal of Botany, 37 (4): 889-898.

Kaur M, Kaur R, Sharma C, Kaur N, Kaur A, 2014. Effect of Growth Regulators on Micropropagation of Potato Cultivars. Journal of Cell \& Tissue Research, 14 (1): 4363-4366.

Koda Y, Kikuta Y, Tazaki H, Tsujino Y, Sakamura S, Yoshihara T, 1991. Potato Tuber-Inducing Activities of Jasmonic Acid Related Compounds. Phytochemistry, 30 (5): 1435-1438.

Kolachevskaya OO, Lomin SN, Arkhipov DV, Romanov GA, 2019. Auxins in Potato: Molecular Aspects and Emerging Roles in Tuber Formation and Stress Resistance. Plant Cell Reports, 38: 681-698.

Kovac M, Ravnikar M, 1994. The Effect of Jasmonic Acid on the Photosynthetic Pigments of Potato Plants Grown In Vitro. Plant Science, 103 (1): 11-17.

Kumlay AM, Eryiğit, T, 2011. Growth and Development Regulators in Plants: Plant Hormones, Iğdır University Journal of the Institute of Science and Technology, 1 (2): 47-56. 
Kumlay A, 2014. Combination of the Auxins NAA, IBA, and IAA with $\mathrm{GA}_{3}$ Improves the Commercial Seed-Tuber Production of Potato (Solanum tuberosum L.) Under in vitro Conditions. BioMed Research International, Volume 2014, Article ID 439259, 7 pages.

Kumlay AM, Arslan N, Kaya C, 2014a. Factors Affecting Microtuberization of Potato (Solanum tuberosum L.) on in vitro Conditions. Anadolu Journal of Agriciultural Sciences, 29 (2): 154165.

Kumlay AM, Arslan, N, Kaya C, 2014b. The Effect of Plant Growth Regulators on In Vitro Grown Potato (Solanum tuberosum L.) Explants Under Different Photoperiod Conditions. Iğdır University Journal of the Institute of Science and Technology, 4 (2): 83-94.

Kumlay AM, 2016. The Effect of Jasmonic Acid on the Micropropagation of Potato (Solanum tuberosum L.) Under Long Day Conditions. Yüzüncüyıl University Journal of Agricultural Sciences, 26 (1): 79-88.

Martin-Closas LI, Sol S, Pelacho AM, 2000. Potential Application of Jasmonic Acid for Solanum tuberosum Micropropagation. Part 10: Application of Biotechnology and Molecular Biology and Breeding-In vitro Culture, (Eds. van der Plas LHW and de Klerk GJ), ISHS Acta Horticulturae, XXV International Horticultural Congress, 2-7, August 1998, Brussels, Belgium, 520: 127-134.

Mehmood A, Shah AH, Sajid M, Ahmad H, 2016. Investigation of GA 3 Effect on In Vitro Micropropagation of Potato Varieties. International Journal of Agronomy and Agricultural Research, 9 (5): 21-30.

Mendel P, Schiavo-Capri E, Lalge AB, Vyhnanek T, Kalousek P, Trojan V, Havel L, Filippi A, Braidot E, 2020. Evaluation of Selected Characteristics in Industrial Hemp after Phytohormonal Treatment. Pakistan Journal of Agricultural Science, 57 (1): 1-7.

Molla MMH, Nasiruddin KM, Al-Amin M, Khana ASMMR., Salam MA, 2011. Effect of 6-Benzyl Aminopurine, Thidiazuron and Zeatin Riboside on Direct Regeneration of Potato. SAARC Journal of Agriculture, 9 (1): 55-68.

Mohapatra PP, BatraVK, 2017. Tissue Culture of Potato (Solanum tuberosum L.): A Review. International Journal of Current Microbiology and Applied Sciences, 6 (4): 489-495.

Naqvi B, Abbas H, Ali H, 2019. Evaluation of In Vitro Tuber Induction Ability of Two Potato Genotypes. Pakistan Journal of Agricultural Science, 56 (1): 77-81.

Nuwagira F, Mukasa SB, Wagoire WW, Namugga P, Kashaija IN, Barekye A, 2015. Determination of Hormonal Combination for Increased Multiplication of Tissue Culture Potato Plantlets. Uganda Journal of Agricultural Sciences, 16 (1): 129-137.

Pelacho AM, Perez-Katalan J, Martin-Closas LI, 1997. Root Development In Vitro Potato Explants as Affected by Jasmonic Acid. Biology of Root Formation and Development, In: Basic Life Sciences, (Eds. Altman A, Waisel Y), 65: 141-145.

Pruski K, 2007. The Canon of Potato Science: In Vitro Multiplication through Nodal Cuttings. Potato Research, 50 (3-4): 293-296.

Quiroz KA, Berríos M, Carrasco B, Retamales JB, Caligari PDS, García-Gonzáles R, 2017. Meristem Culture and Subsequent Micropropagation of Chilean strawberry (Fragaria chiloensis (L.) Duch.). Biological Research, 50 (1):20.

Rabbani A, Askari B, Abbasi NA, Bhatti M, Quraishi A, 2001. Effect of Growth Regulators on In Vitro Multiplication of Potato. International Journal of Agriculture and Biology, 3 (2): 181-182.

Ravnikar M, Rode J, Gogala N, Benedicic D, 1990. Regulation of Organogenesis with Jasmonic Acid. ISHS Acta Horticulturae (Eds. Janick J, Zimmerman RH), I. International Symposium on In vitro Culture and Horticultural Breeding, Bologna, Italy, 280: 169-172. 
Ravnikar M, Vilhar B, Gogala N, 1992. Stimulatory Effects of Jasmonic Acid on Potato Stem Node and Protoplast Culture. Journal of Plant Growth Regulation, 11 (1): 29-33.

Tazeb A, 2017. Plant Tissue Culture Techniques as A Novel Tool in Plant Breeding: A Review Article. American-Euroasian Journal of Agricultural \& Environmental Sciences, 17 (2): 111-118.

Uddin NS, 2006. In Vitro Propagation of Elite Indigenous Potato (Solanum tuberosum L. var. Indurkani) of Bangladesh. Journal of Plant Science, 1 (3): 212-216.

van den Berg, JH, Ewing EE, 1991. Jasmonates and Their Role in Plant Growth and Development, with Special Reference to the Control of Potato Tuberization: A Review. American Potato Journal, 68 (11): 781-794.

Vilhar B, Ravnikar M, Francis D, 1997. Jasmonic Acid Affects Cell Division in Meristems of Cultured Potato Roots. Biology of Root Formation and Development (In: Basic Life Sciences, Eds. Altman A, Waisel Y), Springer, New York, USA, 65: 105-110.

Wani AM, Jamir LL, Rai P, 2018. Effects of IBA, NAA and $\mathrm{GA}_{3}$ on Rooting and Morphological Features of Ginkgo biloba Linn. Stem Cuttings. Journal of Pharmacognosy and Phytochemistry, 7(3): 1894-1896.

Xhulaj DB, Gixhari B, 2018. In Vitro Micropropagation of Potato (Solanum tuberosum L) Cultivars. Agriculture and Forestry, 64 (4): 105-112.

Xhulaj DB, 2019. Shoot Regeneration of Potato Cultivar "Montecarlo" Using Tissue Culture. Eds. Mioč B, Širić I, 54th Croatian and 14th International Symposium on Agriculture, February 17-22, 2019, Vodice, Croatia, p: 218-222.

Zhang Z, Cheng ZM, 1996. The Effect of Jasmonic Acid on In Vitro Nodal Culture of Three Potato Cultivars. HortScience, 31 (4): 631.

Zhang ZJ, Zhou WJ, Li HZ, Zhang GQ, Subrahmaniyan K, Yu JQ, 2006. Effect of Jasmonic Acid on In Vitro Explant Growth and Microtuberization in Potato. Biologia Plantarum, 50 (3): 453-456. 